\title{
Relaxin protein and gene expression in ovarian follicles of immature pigs
}

\section{K M Ohleth, Q Zhang and C A Bagnell}

Department of Animal Sciences, Rutgers University, New Brunswick, New Jersey 08901-8525, USA

(Requests for offprints should be addressed to C A Bagnell)

\begin{abstract}
Relaxin production by the ovarian follicle of gonadotropin-primed, prepubertal gilts is well documented. As far as we are aware, a source of relaxin in pig follicles, independent of gonadotropins, has not yet been reported. Therefore, the objective of this study was to determine whether relaxin is produced in porcine follicles in the absence of exogenous or cyclic gonadotropins. In immature pigs, immunoreactive relaxin was detected in fluids from small $(1-3 \mathrm{~mm})$, medium $(4-5 \mathrm{~mm})$ and large $(>6 \mathrm{~mm})$ follicles and localized to the theca interna of large follicles. Relaxin levels in follicular fluid significantly increased with follicle size $(P<0 \cdot 05)$. Relaxin mRNA was detected in
\end{abstract}

whole small- and medium-sized follicles. In large follicles, the relaxin gene was expressed in thecal layers, but not granulosa cells. The abundance of relaxin transcript did not change with follicle size. In summary, relaxin protein and mRNA were detected in porcine follicles from immature animals, indicating that relaxin is produced in the porcine follicle in the absence of exogenous or cyclic gonadotropins. Relaxin's in vitro growth effects on porcine granulosa and theca cells support this follicular relaxin as a growth modulator during porcine follicular development.

Fournal of Molecular Endocrinology (1998) 21, 179-187

\section{INTRODUCTION}

The corpus luteum (CL) is well established as the primary source of ovarian relaxin in the pig (Ali et al. 1986, Fields \& Fields 1985, Bagnell et al. 1990a). The first studies to support a follicular source of relaxin were reported in 1980, when relaxin was found in media of follicle wall cultures and follicular fluid from pregnant and non-pregnant pigs (Bryant-Greenwood et al. 1980). Evidence that this represented a non-luteal source of relaxin came from the studies of Matsumoto \& Chamley (1980) who showed immunoreactive relaxin in ovarian extracts and follicular fluid of immature pigs. The specific cellular source of relaxin in the pig follicle was identified as the theca cell (TC) in larger, more developed follicles from gonadotropin-primed pigs (Bagnell et al. 1987, 1990b). In vitro relaxin production was also detected by thecal explants from gonadotropin-primed pigs (Evans et al. 1983), and by preovulatory porcine granulosa cells (GC) after treatment with luteinizing hormone (LH) (Loeken et al. 1983). Thus, while there is evidence that exogenous gonadotropins stimulate relaxin production by porcine follicular tissue, whether follicular relaxin is produced in the absence of exogenous gonadotropins has not been reported.

The growth-promoting effects of low levels of relaxin in vitro on porcine $\mathrm{GC}$ and $\mathrm{TC}$ from follicles of all sizes (Zhang \& Bagnell 1993, 1994) points to a local source of relaxin in mediating follicle growth in vivo. Although the presence of relaxin in follicular fluid has been attributed to diffusion from nearby CL (Bryant-Greenwood et al. 1980), the source of follicular relaxin in the absence of CL (Matsumoto \& Chamley 1980) has never been identified. Therefore, the objective of the present study was to investigate whether relaxin is produced by ovarian follicles from immature pigs. We chose to use immature pigs to avoid the possibility of diffusion of relaxin from nearby CL and eliminate the impact of cyclic gonadotropins on follicular relaxin production. In small, medium and large follicles from immature pigs, relaxin protein was measured in follicular fluid using a homologous radioimmunoassay, and sought by immunohistochemistry using specific porcine relaxin antisera. In addition, semi-quantitative reverse transcriptase-polymerase chain reaction (RT-PCR) was used to characterize relaxin gene expression in different sized porcine follicles. 


\section{MATERIALS AND METHODS}

\section{Materials}

Purified, monoacylated porcine relaxin was provided by Dr G D Bryant-Greenwood (University of Hawaii, Honolulu, HI, USA). Relaxin antisera (R6) for the relaxin radioimmunoassay was a gift from Dr B G Steinetz (New York University Medical Center, New York, USA). Antisera to purified porcine relaxin $(\mathrm{Gg})$ used for immunostaining was raised in a rabbit by the method of Vaitukaitis et al. (1971) and provided by Dr G D BryantGreenwood, (University of Hawaii). The Vectastain $\mathrm{ABC}$ kit and normal rabbit serum were obtained from Vector Laboratories, Inc. (Burlingame, CA, USA) for immunostaining experiments. The GeneAmp PCR Reagent Kit, including AmpliTaq polymerase, was purchased from The Perkin-Elmer Corp. (Norwalk, CT, USA). The Moloney murine leukemia virus reverse transcriptase (MMLV-RT) and RNasin RNase inhibitor were obtained from Promega Corp. (Madison, WI, USA), and random primers were purchased from Life Technologies, Inc. (Grand Island, NY, USA). PCR primers for porcine relaxin were synthesized by Genosys Biotechnologies, Inc. (The Woodlands, TX, USA). PCR primers and competimers (alternate pair) for $18 \mathrm{~s}$ ribosomal RNA (18 s rRNA) were obtained from Ambion, Inc. (Austin, TX, USA).

\section{Collection of follicular fluid and tissue}

Ovaries from immature gilts $(73-82 \mathrm{~kg})$ were collected at a local slaughterhouse. Only follicles considered morphologically healthy according to the criteria of Moor et al. (1978) were used for collection of follicular fluid and tissue. Fluid was collected by needle aspiration from small $(1-3 \mathrm{~mm})$, medium $(4-5 \mathrm{~mm})$ and large $(>6 \mathrm{~mm})$ follicles. Follicular fluid was gathered from more than ten different collections taken over a period of 6 months. At each collection, fluid from follicles of the same size class were pooled, centrifuged at $500 \mathrm{~g}$ for $10 \mathrm{~min}$ to remove cellular debris and stored at $-80{ }^{\circ} \mathrm{C}$. For each follicle size, the number of pooled follicular fluid samples analyzed for relaxin content was: small, $n=19$; medium, $n=17$; and large, $n=9$.

For gene expression studies, follicular tissue was isolated and frozen on-site at a local slaughterhouse to decrease the chance of RNA degradation during subsequent travel and follicle isolation. Groups of small $(1-3 \mathrm{~mm})$ and medium follicles $(4-5 \mathrm{~mm})$ were dissected from the ovaries and frozen. Large follicles $(6 \mathrm{~mm}$ and $>7 \mathrm{~mm})$ were excised from the ovary and cut in half. In order to determine the cellular source of relaxin in these follicles, TC and GC were separated. After GC were gently scraped from follicle linings and collected into a petri dish containing M199, the remaining follicle wall, containing theca interna, theca externa and connective tissue, was frozen in liquid nitrogen. GCs in M199 were pelleted by centrifugation and frozen in liquid nitrogen. Between three and four pools of tissue from each follicle size were collected for isolation of total RNA.

\section{Radioimmunoassay for relaxin}

Relaxin levels in follicular fluid from developing follicles were determined using a homologous porcine relaxin radioimmunoassay (Afele et al. 1979) with modifications. Monoacylated porcine relaxin was iodinated using chloramine $\mathrm{T}$ (Greenwood et al. 1982). Anti-porcine relaxin antibody (R6; $50 \mu \mathrm{l}$ 1:30 000) was incubated with $300 \mu \mathrm{l}$ follicular fluid for $24 \mathrm{~h}$ at $4{ }^{\circ} \mathrm{C}$, and ${ }^{125} \mathrm{I}$-relaxin (12 000 c.p.m.; $50 \mu \mathrm{l}$ ) was added for an additional $24 \mathrm{~h}$ at $4{ }^{\circ} \mathrm{C}$. Separation of bound and free hormone was carried out by conventional double-antibody procedure. Assay sensitivity was $66 \mathrm{pg} / \mathrm{ml}$ and specificity of this assay has been described previously (Bryant-Greenwood \& Greenwood 1979). Inter and intra-assay coefficients of variation were $8 \cdot 6 \pm 1 \cdot 6$ and $6 \cdot 2 \pm 0 \cdot 5 \%$, respectively.

\section{Tissue preparation and immunohistochemistry}

In order to distinguish different sized follicles at the histologic level, ovaries were cut into small pieces containing either small and medium or large follicles, prior to fixation. Tissues were fixed in Bouin's solution for $24 \mathrm{~h}$ at room temperature, dehydrated in increasing concentrations of alcohol and embedded in paraffin. Prior to immunostaining, the tissues were sectioned at $7 \mu \mathrm{m}$, mounted on glass slides with gelatin, deparaffinized, and rehydrated in decreasing concentrations of alcohol. At least four different animals were studied for each follicle size.

Relaxin was localized in tissue sections as described by Hsu et al. (1981) using the Vectastain ABC kit (Vector Laboratories, Inc.). All steps were performed at room temperature in a humidified chamber. Briefly, sections were pretreated with $0.3 \%$ hydrogen peroxide for $10 \mathrm{~min}$ to remove endogenous peroxidase activity. Non-specific binding sites for immunoglobulin $\mathrm{G}$ (IgG) were saturated with $3.0 \%$ normal goat serum (NGS) for $20 \mathrm{~min}$. Tissues were then incubated for $1 \mathrm{~h}$ with rabbit antiporcine relaxin serum or normal rabbit serum (NRS) diluted 1:500 in phosphate-buffered 
saline $(0.015 \mathrm{M} ; \mathrm{PBS})$ with $1.0 \%$ NGS. The appropriate dilution of relaxin antisera for immunostaining was previously determined (Bagnell et al. 1987). After $2 \times 3 \mathrm{~min}$ washes in PBS, tissue sections were incubated with biotinylated goat antirabbit IgG for $30 \mathrm{~min}$, and washed $2 \times 3 \mathrm{~min}$ in PBS. Sections were then covered with the $\mathrm{ABC}$ reagent for $45 \mathrm{~min}$. After washing, peroxidase activity was visualized by incubation with 3,3'-diaminobenzidine tetrahydrochloride in $0.01 \%$ hydrogen peroxide/ $0.1 \mathrm{M}$ Tris-HCl buffer $(\mathrm{pH} 7 \cdot 2)$ for 2-8 min. The sections then were rinsed in water, counterstained with hematoxylin, and mounted using Permount. Sections of CL obtained from non-pregnant sows at day 15 of the estrous cycle, known to contain immunoreactive relaxin (Ali et al. 1986), were used as a positive control, and to control for interexperiment reproducibility. Method specificity was tested by substituting NRS for the rabbit antiporcine relaxin serum. Antiserum specificity was demonstrated by preabsorbing the relaxin antiserum with purified porcine relaxin $(100 \mathrm{ng} / \mathrm{ml})$ at $4{ }^{\circ} \mathrm{C}$ for $48 \mathrm{~h}$ prior to use.

\section{Total RNA isolation}

Total RNA was isolated from follicular tissue as previously described by Cathala et al. (1983) with modifications (Ryan et al. 1996). Tissues were homogenized in GT buffer (4 M guanidine thiocyanate; $50 \mathrm{mM}$ Tris- $\mathrm{HCl}, \mathrm{pH} 7 \cdot 5 ; 10 \mathrm{mM}$ EDTA; $0.5 \%$ sodium N-lauroyl sarcosine, $8 \%$ 2-mercaptoethanol; $10 \mathrm{ml} / \mathrm{g}$ tissue) and homogenates were precipitated with 5 volumes $4 \mathrm{M} \mathrm{LiCl}$. After centrifugation, the precipitate was resuspended in $2.5 \mathrm{ml}$ TES buffer $(50 \mathrm{mM}$ Tris- $\mathrm{HCl}$, $\mathrm{pH} 7 \cdot 5 ; 5 \mathrm{mM}$ EDTA; $0 \cdot 5 \% \mathrm{SDS}$ ) and digested in proteinase $\mathrm{K}$ (Life Technologies). The remaining solution was then extracted with phenol:chloroform: isoamyl (25:24:1) and chloroform:isoamyl (24:1). Total RNA was ethanol precipitated, rinsed with ice-cold $80 \%$ ethanol, dried and resuspended in diethylpyrocarbonate-treated water. Quantity and purity of the RNA was assessed spectrophotometrically at 260 and $280 \mathrm{~nm}$.

\section{Reverse transcriptase-polymerase chain reaction}

Although Northern analysis has been used to detect follicular relaxin gene expression in gonadotropinprimed prepubertal pigs, preliminary experiments indicated that this approach was not sensitive enough to detect the low copy relaxin transcript expected in follicles from immature pigs. Therefore, relaxin mRNA expression in follicular tissue was monitored using RT-PCR as described by Knox et al. (1994) with modifications, and quantified relative to the amount of $18 \mathrm{~s}$ rRNA. DNA contamination was eliminated as reported by Huang et al. (1996) with modifications. Briefly, $1 \mu \mathrm{g}$ total RNA was incubated at $37^{\circ} \mathrm{C}$ for $30 \mathrm{~min}$ in $1 \times$ MMLV-RT reaction buffer; $1.5 \mu \mathrm{g}$ random primers; $125 \mu \mathrm{M}$ dATP, dCTP, dGTP and dTTP; 1 U DNase (RNase-free); and $20 \mathrm{U}$ RNasin (RNase inhibitor). Subsequently, the DNase was inactivated for $7 \mathrm{~min}$ at $75^{\circ} \mathrm{C}$, and $200 \mathrm{U}$ MMLV-RT were added for a $45 \mathrm{~min}$ reaction at $42{ }^{\circ} \mathrm{C}$. A blank was included with each set of DNase-treated, RT samples, in which sterile water was substituted for RNA in the DNA elimination and RT reactions.

Primer sequences used to amplify porcine relaxin cDNAs were synthesized as described by Knox et al. (1994) and are specific for the 5'-(TACAGCA GCTGCAGTATCTA-OH) and 3'-(TGTCACTGA GAATACATGTG-OH) untranslated regions of the relaxin gene. Relaxin and $18 \mathrm{~s}$ rRNA alternate primers:competimers (Ambion, Inc.) generated fragments of 663 and 324 base pairs respectively. Five- and one-microliter aliquots of the RT reaction were used to amplify relaxin and $18 \mathrm{~s}$ rRNA fragments respectively, with the GeneAmp DNA Reagent Kit in the following $50 \mu$ reaction: $1 \times$ PCR buffer II; $2 \mathrm{mM}$ $\mathrm{MgCl}_{2} ; 50 \mu \mathrm{M}$ each of dATP, dCTP, dGTP and dTTP; 10 pmol $5^{\prime}$ - and $3^{\prime}$ - relaxin primers or $18 \mathrm{~s}$ rRNA primers:competimers $(8: 2 ; 4 \mu \mathrm{l})$; and $1.25 \mathrm{U}$ AmpliTaq polymerase. Amplification of relaxin and $18 \mathrm{~s}$ rRNA cDNAs was performed for 30 and 15 cycles respectively, each cycle consisting of $1 \mathrm{~min}$ denaturation at $95^{\circ} \mathrm{C}, 45 \mathrm{~s}$ annealing at $56^{\circ} \mathrm{C}$ and 1 min extension at $72^{\circ} \mathrm{C}$ in the Ericomp DeltaCycler I System (Ericomp, Inc., San Diego, CA, USA). Each set of PCR included the appropriate volume of the RT blank described above. A pool of follicle RNA from pigs 60 and $72 \mathrm{~h}$ after equine chorionic gonadotropin (eCG)treatment, which contains relaxin mRNA (Bagnell et al. 1990b), and liver from neonatal pigs, were used as positive and negative controls for relaxin transcript respectively. The post-eCG follicle pool was included in each set of RT-PCR to account for variability between each set of reactions. To verify that relaxin and $18 \mathrm{~s}$ rRNA cDNAs were amplified in the exponential range, an RT reaction of the post-eCG follicle pool was serially diluted (up to 1:32) and each dilution was used as template for relaxin and $18 \mathrm{~s}$ rRNA PCR.

\section{Southern analysis}

PCR products were fractionated on $5 \%$ polyacrylamide-Tris-borate-EDTA gels at $100 \mathrm{~V}$ in Tris $(90 \mathrm{mM})$-borate $(90 \mathrm{mM})$-EDTA $(2 \mathrm{mM})$ buffer $(1 \times$ TBE) . Gels were stained with ethidium 
bromide $(0.5 \mu \mathrm{g} / \mathrm{ml})$ for $15 \mathrm{~min}$, destained in distilled, deionized water for $15 \mathrm{~min}$ and photographed. Gels containing relaxin PCR fragments were prepared for Southern analysis by denaturing in $0.25 \mathrm{M} \mathrm{NaOH}$ for $5 \mathrm{~min}$ and neutralizing in $1 \times$ TBE for 10 min prior to transfer. Amplified relaxin cDNAs were electrophoretically transferred to BrightStar-Plus, positively-charged, nylon membranes (Ambion, Inc.) in $0.5 \times \mathrm{TBE}$ with $400 \mathrm{~mA}$ for $1 \mathrm{~h}$. Nucleic acids were fixed with $0 \cdot 4 \mathrm{M} \mathrm{NaOH}$ for $10 \mathrm{~min}$ and crosslinked to the membrane with UV light (Stratalinker, Stratagene, Inc., La Jolla, CA, USA ).

Relaxin antisense riboprobe was transcribed in a large scale reaction using the Gemini System (Promega Corp.). The riboprobe was labeled with biotin by irradiating $10 \mu \mathrm{l}$ probe $(50 \mathrm{ng} / \mu \mathrm{l})$ with long wave UV light $(366 \mathrm{~nm})$ in the presence of psoralen-biotin for $45 \mathrm{~min}$ in the well of a microtiter plate on ice, according to the manufacturer's directions (Ambion, Inc.). Excess psoralenbiotin was removed from the labeled probe with two butanol extractions. The biotin-labeled relaxin probe was then used in Southern analysis of PCR products to detect relaxin fragments. The membranes were prehybridized at $42{ }^{\circ} \mathrm{C}$ for $15 \mathrm{~min}$ in hybridization buffer $(10 \mathrm{ml})$ containing $50 \%$ formamide; $6 \times \mathrm{SSPE}(1 \times \mathrm{SSPE}=150 \mathrm{mM} \mathrm{NaCl}$; $11.5 \mathrm{mM} \mathrm{NaH}{ }_{2} \mathrm{PO}_{4} ; 1 \mathrm{mM}$ EDTA); $5 \times$ Denhardt's; $0 \cdot 5 \%$ SDS and $50 \mu \mathrm{g} / \mathrm{ml}$ salmon testes DNA. Subsequently, the membranes were hybridized with biotinylated relaxin riboprobe in hybridization buffer $(10 \mathrm{ng} / \mathrm{ml} ; 5 \mathrm{ml})$ overnight at $42^{\circ} \mathrm{C}$. Membranes were then washed in the following: $2 \times \mathrm{SSC}$, $0 \cdot 5 \%$ SDS $(1 \times \mathrm{SSC}=150 \mathrm{mM}$ sodium chloride; $15 \mathrm{mM}$ sodium citrate) for $5 \mathrm{~min}$ at $22^{\circ} \mathrm{C} ; 2 \times \mathrm{SSC}$, $0.1 \% \operatorname{SDS}$ for $20 \mathrm{~min}$ at $22{ }^{\circ} \mathrm{C} ; 0 \cdot 1 \times \mathrm{SSC}, 0 \cdot 5 \%$ SDS for $20 \mathrm{~min}$ at $37^{\circ} \mathrm{C} ; 0 \cdot 1 \times \mathrm{SSC}, 0 \cdot 5 \% \mathrm{SDS}$ for $20 \mathrm{~min}$ at $65^{\circ} \mathrm{C}$; and $0 \cdot 1 \times \mathrm{SSC}$ for $20 \mathrm{~min}$ at $22^{\circ} \mathrm{C}$.

Relaxin antisense probe hybridized to relaxin PCR products was detected using the BrightStar BioDetect Nonisotopic Detection Kit (Ambion, Inc.). All steps of the detection procedure were performed at room temperature with rocking. The membranes were washed $2 \times 5 \mathrm{~min}$ in wash buffer; $2 \times 5$ min in blocking buffer; and $30 \mathrm{~min}$ in blocking buffer. Subsequently, the membranes were incubated with a streptavidin-alkaline phosphatase conjugate for $30 \mathrm{~min}$, and washed $10 \mathrm{~min}$ in blocking buffer; $3 \times 5 \mathrm{~min}$ in wash buffer; $2 \times 2 \mathrm{~min}$ in assay buffer; with a final incubation in the CDP-Star chemiluminescent reagent for $5 \mathrm{~min}$. On the following day, the membranes were exposed to X-ray film (Hyperfilm-ECL; Amersham Corp., Arlington Heights, IL, USA) for 2-15 min. X-ray film images (relaxin PCR products) and Polaroid negatives (18 $\mathrm{s}$ PCR products) were scanned into the computer using Adobe Photoshop 4.0 (Adobe Systems, Inc., San Jose, CA, USA). The area of pixel unit intensity (optical density units $=O D_{\text {units }}$ ) for each band was determined with SigmaGel $1 \cdot 0$ (Jandel Scientific Software, San Rafael, CA, USA). The positive control, post-eCG follicle PCR products from the appropriate set of RT-PCR were run on each gel. To correct for variability between the Southern blotting and non-radioactive detection procedures, optical densities generated from the relaxin and $18 \mathrm{~s}$ PCR products of each sample were divided by the densitometric value of the relaxin and $18 \mathrm{~s}$ fragments from the follicle pool on the same blot or gel. Subsequently, optical densities of the relaxin cDNAs were corrected to the optical density of the $18 \mathrm{~s}$ rRNA cDNAs of the same sample.

\section{Statistics}

The correlation between relaxin concentrations in follicular fluid and follicle size was determined using linear regression analysis. To calculate the mean concentration of relaxin in follicular fluid, each sample below the detection limit of the assay was assigned a value of $33 \mathrm{pg} / \mathrm{ml}$, the midpoint of the detection limit of the assay $(66 \mathrm{pg} / \mathrm{ml})$. The midpoint of the assay detection limit was chosen since a value of zero would under-estimate mean relaxin concentrations, whereas $66 \mathrm{pg} / \mathrm{ml}$ would over-estimate mean relaxin levels. For statistical analysis of the gene expression results, optical densities from at least three pools of tissue from each follicle size were compared. Analysis of Variance and Duncan's Multiple Range Test were used to analyze radioimmunoassay and RT-PCR data. A $P<0.05$ was accepted as significant.

\section{RESULTS}

\section{Relaxin protein in the follicular fluid of developing follicles}

Immunoreactive relaxin was detected in fluid from follicles of all sizes. Figure 1 illustrates the range and variation in relaxin concentrations of follicular fluid from different sized follicles. There was a positive correlation between increasing follicle size and relaxin concentration $(y=-332 \cdot 9+241 \cdot 9 x$; $r=0.694 ; P<0 \cdot 01)$. Some of the values were below the detection limit of the assay. For example, in small follicles, relaxin was detected in 6 of 19 samples and ranged from 371 to $843 \mathrm{pg} / \mathrm{ml}$. In medium follicles, relaxin concentrations in 11 of 17 


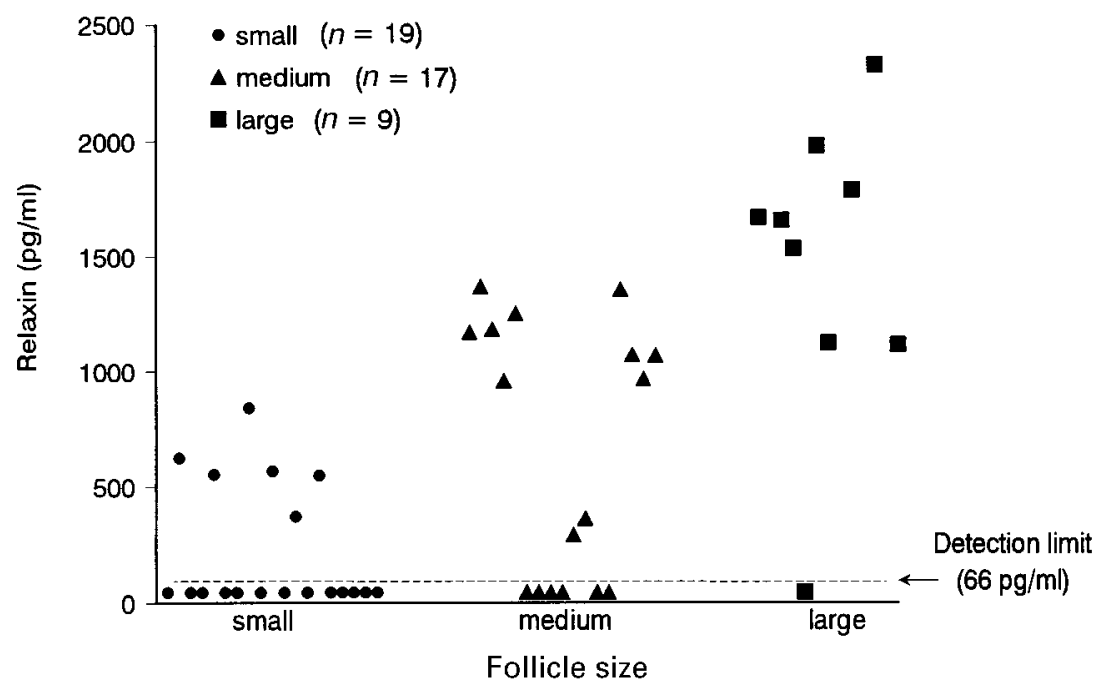

FIGURE 1. Relaxin content of fluids from porcine follicles of increasing size. Fluids from pools of small $(1-3 \mathrm{~mm} ; n=19)$, medium $(4-5 \mathrm{~mm} ; n=17)$ and large $(>6 \mathrm{~mm} ; n=9)$ follicles of prepubertal pigs were collected by needle aspiration. Relaxin was measured using a homologous radioimmunoassay.

samples above the detection limit of the assay, ranged between 292 and $1369 \mathrm{pg} / \mathrm{ml}$. In large follicles, eight of nine samples had detectable relaxin levels, which ranged from 1114 to $1989 \mathrm{pg} /$ $\mathrm{ml}$. Mean relaxin levels in follicular fluid significantly increased with follicle size $(P<0.05)$, and averaged $185 \pm 67,650 \pm 139$, and $1465 \pm 223 \mathrm{pg} / \mathrm{ml}$ for small, medium and large follicles respectively.

\section{Localization of relaxin in developing follicles by immunostaining}

Immunoreactive relaxin was localized in the theca interna layer, but not the granulosa layer, of large porcine follicles (Fig. 2a). When normal rabbit serum was substituted for the relaxin antisera, relaxin immunostaining was not evident in the theca of the large follicle (Fig. 2b). Preabsorption of relaxin antisera with purified relaxin also abolished specific relaxin immunostaining (Fig. 2c). There was no evidence for immunoreactive relaxin in the TC of small- or medium-sized follicles (data not shown). In addition, immunoreactive relaxin was not present in morphologically atretic follicles of any size (data not shown).

\section{Relaxin mRNA in porcine follicles of different sizes}

A linear relationship was observed between relaxin and $18 \mathrm{~s}$ rRNA PCR product yields and the dilutions of positive control $\mathrm{R} T$ reaction used as template in the PCR (data not shown). Relaxin gene expression was detected in whole small $(1-3 \mathrm{~mm})$ and medium (4-5 mm) follicles (Fig. 3a). In follicle walls containing thecal layers, relaxin mRNA was expressed in larger follicles $(6 \mathrm{~mm}$ and $>7 \mathrm{~mm}$; Fig. $3 b$ and c). However, relaxin transcript was not detected in GC from $6 \mathrm{~mm}$ and $>7 \mathrm{~mm}$ follicle groups (Fig. $3 \mathrm{~b}$ and c). In addition, relaxin mRNA was not found in liver from neonatal pigs, used as a negative control for relaxin transcript (Fig. 3b). While relaxin transcript was found in small, medium and large follicles, there was no difference in the relative abundance of relaxin mRNA between follicle sizes.

\section{DISCUSSION}

This study is the first to demonstrate that relaxin protein and gene are expressed in porcine follicles, independent of cyclic or exogenous gonadotropins. In ovaries of immature animals, relaxin protein was detected in follicular fluid by RIA and localized in the TC of the follicle wall by immunohistochemistry. The presence of relaxin mRNA in small-, medium- and large-sized follicles, detected by RT-PCR, supports the concept that these follicles are a source of relaxin protein. The data reported here, together with the in vitro growth-promoting effects of relaxin on $\mathrm{GC}$ and $\mathrm{TC}$ from developing porcine follicles (Zhang \& Bagnell 1993, 1994), support the hypothesis of relaxin as a modulator of 

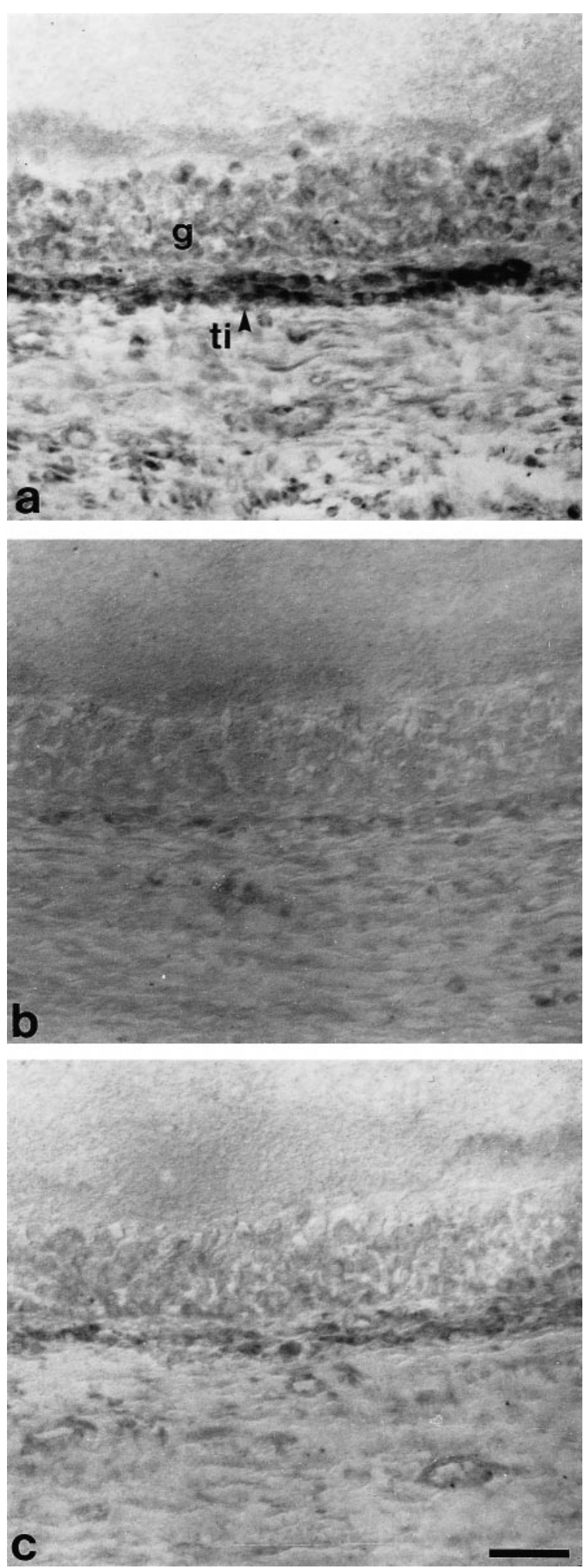

follicular growth. Relaxin produced by the pig follicle may act in an autocrine/paracrine manner to stimulate GC and TC growth associated with follicular development.

The data presented here support the original reports indicating the presence of relaxin in fluid from large follicles of non-pregnant (BryantGreenwood et al. 1980) and immature pigs (Matsumoto \& Chamley 1980). In addition, the present study extends these findings in two ways. By focusing on follicles recovered from ovaries without CL, we ruled out the CL as a source of relaxin in follicular fluid analyzed in our study. We also demonstrated the presence of relaxin mRNA not only in large follicles, but also in small- and medium-sized pig follicles. Furthermore, the concentration of relaxin in follicular fluid significantly increased with follicle size. However, there was considerable variation in relaxin content within each follicle-size class. A similar variation in relaxin levels is also reported in follicular fluid of women (Wathes et al. 1986) and horses (Ryan et al. 1997). The explanation for the high variation of relaxin in follicular fluid is unknown. However, diffusion of relaxin from larger follicles to small and medium follicles is a possibility and could be a source of variation. Another explanation may be that individual follicles differ in their rates of relaxin transcription, translation and/or secretion, leading to variable levels of relaxin protein and message in different follicles.

The fact that we found relaxin protein and gene expression in porcine follicles, independent of cyclic or exogenous gonadotropin stimulation, demonstrates that elevated gonadotropins are not a prerequisite for follicular relaxin production. This finding is important since several studies demonstrate that relaxin is produced in the follicle in response to exogenous gonadotropin administration in a number of species. When prepubertal pigs were given gonadotropins to induce follicular growth and ovulation, relaxin was detected in the follicular fluid (Bagnell 1991), and relaxin gene and protein were localized in TCs (Bagnell et al. 1987, 1990b).

FIGURE 2. Immunolocalization of relaxin in the wall of a large porcine follicle. Immunoreactive relaxin was sought in tissue sections using a specific relaxin antiserum (a; 1:500) and the Vectastain ABC kit. Immunoreactive relaxin localized to the theca interna (ti) layer of the follicle wall. Nearby sections were incubated with either normal rabbit serum (b; 1:500); or relaxin antisera preabsorbed with $100 \mathrm{ng} / \mathrm{ml}$ relaxin (c). Note the reduction in relaxin immunoreaction product in the theca $(b, c)$ when compared with (a). g: GCs; $\operatorname{Bar}=50 \mu \mathrm{m}$ 
a

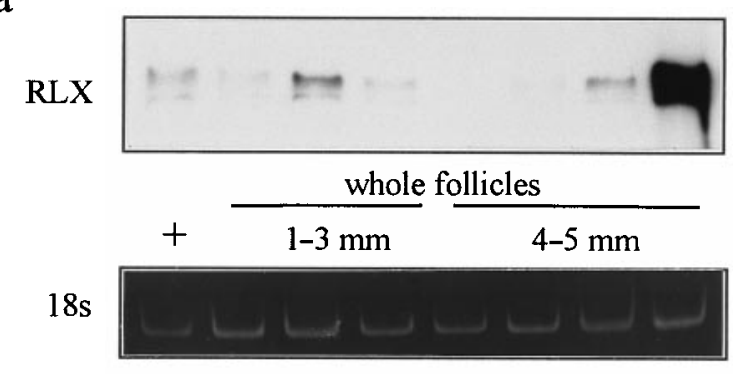

b

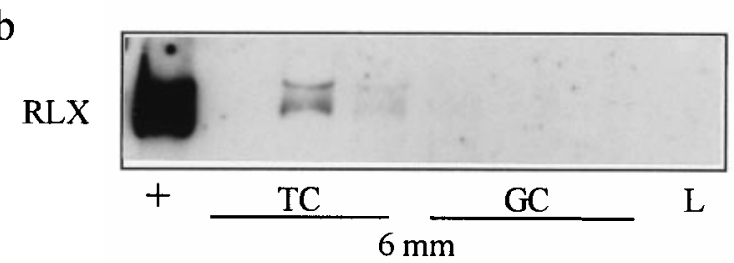

$18 \mathrm{~s}$

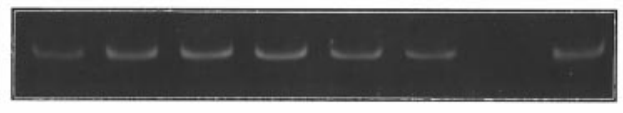

c

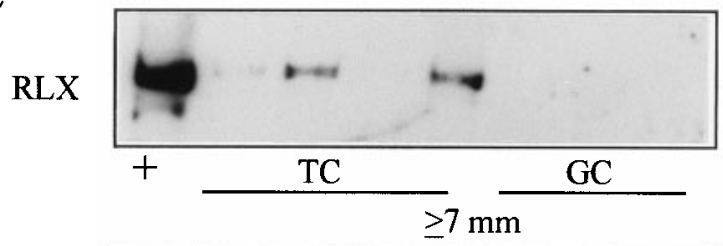

$18 \mathrm{~s}$

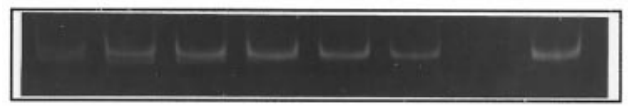

FIGURE 3. Relaxin (RLX) gene expression in different sized porcine follicles. Total RNA was isolated from small (1-3 $\mathrm{mm})$ and medium (4-5 $\mathrm{mm}$ ) whole follicles, and $\mathrm{GC}$ and TC from large follicles $(6 \mathrm{~mm}$ and $>7 \mathrm{~mm})$. Relaxin transcript was detected by RT-PCR and Southern analysis and relatively quantified as described in the Materials and Methods. (a) small $(n=3)$ and medium $(n=4)$ whole follicles; (b) TC $(n=3)$ and GC $(n=3)$ from $6 \mathrm{~mm}$ follicles and the negative control liver sample (L); (c) TC $(n=4)$ and GC $(n=3)$ from follicles $>7 \mathrm{~mm}$. + : positive control.

Relaxin secretion from thecal explants of pigs given exogenous gonadotropins is also stimulated by $\mathrm{LH}$ (Evans et al. 1983). In addition, follicular relaxin is found in women stimulated with gonadotropins (Yki-Jarvinen et al. 1984, Wathes et al. 1986, Haning et al. 1996). In women, baboons and monkeys, plasma relaxin also increases after human chorionic gonadotropin (hCG) administration (Quagliarello et al. 1980, Castracane et al. 1983, Ottobre et al. 1984). Although cyclic or exogenous gonadotropins were absent in the present study, we cannot rule out the possibility that follicular relaxin production is influenced by the low circulating levels of gonadotropins reported in prepubertal gilts (Colenbrander et al. 1982, Diekman et al. 1983, Grieger et al. 1986).

Evidence for the cellular source of relaxin in follicles from immature animals points to the theca, since relaxin transcript was detected in TC of larger-sized follicles. While relaxin production has been reported in porcine and human GC (Gagliardi et al. 1992, Loeken et al. 1983), this was likely due to the luteinization of these GC in culture. Relaxin is also produced by differentiating porcine GC during formation of the CL (Bagnell et al. 1989, 1993b, Denning-Kendall et al. 1989). However, RT-PCR analysis of $\mathrm{TC}$ and $\mathrm{GC}$ from larger follicles in this study indicates that GC do not express relaxin transcript, and therefore, theca are the sole source of follicular relaxin in the prepubertal pig. This relaxin gene expression in $\mathrm{TC}$ is consistent with our immunostaining results which localize immunoreactive relaxin to the $\mathrm{TC}$ of large follicles. Collectively, the data presented here extend the reports of thecal relaxin production in gonadotropin-primed pigs (Bagnell et al. 1987, $1990 b$ ) by showing that exogenous gonadotropins are not required for follicular relaxin expression. Our inability to immunolocalize relaxin in smalland medium-sized follicles may be related to the sensitivity of the immunohistochemical detection system used. This is supported by the fact that relaxin transcript was detected in follicles of all class sizes by RT-PCR. The presence of relaxin mRNA in small and medium follicles indicates that these less mature follicles are capable of producing relaxin.

Of interest in the present study is that the relative abundance of relaxin mRNA did not differ between small, medium and large follicles, while relaxin protein in follicular fluid was significantly correlated with follicle size. The reason for the increase in follicular fluid relaxin without a change in relaxin transcript is unknown. One possibility is that the semiquantitative RT-PCR method used in the present study was insensitive to increases in relaxin mRNA with follicle size. However, this approach accurately detects relative differences in mRNA abundance when both the relaxin and $18 \mathrm{~s}$ cDNAs are amplified within the linear range, which we verified in the validation of our specific RT-PCR protocol. Another possibility is that relaxin in the follicle is translationally regulated, therefore, differences in relaxin protein would be expected without changes in relaxin mRNA. Lastly, it is possible that relaxin gene transcription and hormone secretion in the follicle are independent events. For example, when relaxin secretion and gene expression in 
individual large LC (LLC) were studied using the reverse hemolytic plaque assay coupled with in situ hybridization, a direct correlation between relaxin secretion and relaxin mRNA was not demonstrated in all cells (Bagnell et al. 1993a). While a proportion of LLC that secreted relaxin contained relaxin mRNA, other relaxin-secreting LLC did not express relaxin transcript (Bagnell et al. 1993a). Thus, it is possible that rates of relaxin transcription are different from those of relaxin secretion in LLC, as well as in the follicle. A similar phenomenon has been reported in other protein-secreting cells (Tsang et al. 1990, Scarbrough et al. 1991, Larson \& Wise 1994) and a temporal dissociation between hormone secretion and transcription has been suggested (Tsang et al. 1990, Scarbrough et al. 1991).

In summary, the presence of relaxin protein and mRNA in follicles of increasing size in the immature porcine ovary supports the concept of a follicular source of relaxin. This follicular relaxin may contribute to GC and TC growth associated with follicular development in prepubertal as well as cyclic pigs. Further studies are necessary to identify factors regulating follicular relaxin production, and relaxin's mechanism of action and physiologic roles in the pig ovary.

\section{ACKNOWLEDGEMENTS}

The authors wish to thank Dr G D BryantGreenwood for the monoacylated relaxin and anti-porcine relaxin antibody used for immunostaining; Dr B G Steinetz for the R6 relaxin antibody used for radioimmunoassay; and Leidy's Incorporated for supplying pig ovaries.

\section{REFERENCES}

Afele S, Bryant-Greenwood GD, Chamley WA \& Dax EM 1979 Plasma relaxin immunoreactivity in the pig at parturition and during nuzzling and suckling. Fournal of Reproduction and Fertility 56 451-457.

Ali SM, McMurtry JP, Bagnell CA \& Bryant-Greenwood GD 1986 Immunocytochemical localization of relaxin in corpora lutea of sows throughout the estrous cycle. Biology of Reproduction 34 139-143.

Bagnell CA 1991 Production and biologic action of relaxin within the ovarian follicle: an overview. Steroids $\mathbf{5 6}$ 242-246.

Bagnell CA, Frando LB, Downey BR, Tsang K \& Ainsworth L 1987 Localization of relaxin in the pig follicle during preovulatory development. Biology of Reproduction 37 235-240.

Bagnell CA, Ayau E, Downey BR, Tsang BK \& Ainsworth L 1989 Localization of relaxin during formation of the porcine corpus luteum. Biology of Reproduction 40 835-841.
Bagnell CA, Tashima L, Stark W, Ali SM \& McMurtry JP $1990 a$ Relaxin gene expression in the sow corpus luteum during the cycle, pregnancy and lactation. Endocrinology 126 2514-2520.

Bagnell CA, Tsark W, Tashima L, Downey BR, Tsang BK \& Ainsworth L $1990 b$ Relaxin gene expression in the porcine follicle during preovulatory development induced by gonadotropins. Fournal of Molecular Endocrinology $\mathbf{5}$ 211-219.

Bagnell CA, Ohleth KM, Clark CL \& Taylor MJ $1993 a$ Detection of relaxin secretion and gene expression in individual porcine luteal cells. In Molecular Basis of Reproductive Endocrinology, pp 264-269. Eds PCK Leung, AJW Hsueh \& HG Friesen. New York: Springer-Verlag.

Bagnell CA, Zhang Q, Ohleth K, Connor ML, Downey BR, Tsang BK \& Ainsworth L $1993 b$ Developmental expression of the relaxin gene in the porcine corpus luteum. Fournal of Molecular Endocrinology 10 87-97.

Bryant-Greenwood GD \& Greenwood FC 1979 Specificity of radioimmunoassay for relaxin. Fournal of Endocrinology $\mathbf{8 1}$ 239-247.

Bryant-Greenwood GD, Jeffrey R, Ralph MM \& Seamark RF 1980 Relaxin production by the porcine Graafian follicle in vitro. Biology of Reproduction 23 792-800.

Castracane VD, D'Eletto R \& Weiss G 1983 Relaxin secretion in the baboon (Papio cynocephalus). In Factor Regulating Ovarian Function, pp 415-419. Eds GS Greenwald \& PF Terranova. New York: Raven Press.

Cathala G, Savouret J-F, Mendez B, West BL, Karin M, Martial JA \& Baxter JD 1983 A method for the isolation of intact, translationally active ribonucleic acid. $D N A 2$ 329-335.

Colenbrander B, Van De Wiel DFM, Van Rossum-Kok CMJE \& Wensing CJG 1982 Changes in serum FSH concentrations in the pig during development. Biology of Reproduction 26 105-109.

Denning-Kendall PA, Guldenaar EF \& Wathes DC 1989 Evidence for a switch in the site of relaxin production from small theca-derived cells to large luteal cells during early pregnancy in the pig. Fournal of Reproduction and Fertility $\mathbf{8 5}$ 261-271.

Diekman MA, Trout WE \& Anderson LL 1983 Serum profiles of $\mathrm{LH}, \mathrm{FSH}$ and prolactin from 10 weeks of age until puberty in gilts. Fournal of Animal Science $\mathbf{5 6}$ 139-145.

Evans G, Wathes DC, Kin GJ, Armstrong DT \& Porter DG 1983 Changes in relaxin production by the theca during the preovulatory period of the pig. Fournal of Reproduction and Fertility $69677-683$.

Fields PA \& Fields MJ 1985 Ultrastructural localization of relaxin in the corpus luteum of the nonpregnant, pseudopregnant and pregnant pig. Biology of Reproduction 32 1169-1179.

Gagliardi CL, Goldsmith LT, Saketos M, Weiss G \& Schmidt CL 1992 Human chorionic gonadotropin stimulation of relaxin secretion by luteinized human granulosa cells. Fertility and Sterility 58 314-320.

Greenwood FC, Duyao M, Setliff J, Koay E, MercadoSimmen R, Yamamoto S, Ueno M \& Bryant-Greenwood GC 1982 Problems in the study of relaxin receptors. In Biology of Relaxin and its Role in the Human, pp 159-179. Eds M Bigazzi, FC Greenwood \& F Gasparri. Amsterdam, Oxford, Princeton: Excerpta-Medica.

Grieger DM, Brandt KE \& Diekman MA 1986 Follicular fluid concentrations of estradiol-17 $\beta$ and progesterone and secretory patterns of LH and FSH in prepubertal gilts reared in confinement or outdoor lots. Fournal of Animal Science $62751-758$. 
Haning RV Jr, Goldsmith LT, Seifer DB, Wheeler C, Frishman G, Sarmeno J \& Weiss G 1996 Relaxin secretion in in vitro fertilization programs. American Fournal of Obstetrics and Gynecology 174 233-240.

Hsu SM, Raine L \& Fanger H 1981 The use of avidinbiotin-peroxidase complex $(\mathrm{ABC})$ in immunoperoxidase techniques: a comparison between $\mathrm{ABC}$ and unlabeled antibody (PAP) procedures. Fournal of Histochemistry and Cytochemistry 29 557-580.

Huang Z, Fasco MJ \& Kaminsky LS 1996 Optimization of DNase removal of contaminating DNA from RNA for use in quantitative RNA-PCR. Biotechniques 20 1012-1014.

Knox RV, Zhang Z, Day BN \& Anthony RV 1994 Identification of relaxin gene expression and protein localization in uterine endometrium during early pregnancy in the pig. Endocrinology 135 2517-2525.

Larson GH \& Wise PM 1994 Constitutive and regulated prolactin secretion: effects of estradiol. Biology of Reproduction 50 357-362.

Loeken MR, Channing CP, D’Eletto R \& Weiss G 1983 Stimulatory effect of luteinizing hormone upon relaxin secretion by cultured porcine preovulatory granulosa cells. Endocrinology 112 769-771.

Matsumoto D \& Chamley WA 1980 Identification of relaxin in porcine follicular fluid and in the ovary of the immature sow Fournal of Reproduction and Fertility 58 369-375.

Moor RM, Hay MF, Dott HM \& Cran DG 1978 Macroscopic identification and steroidogenic function of atretic follicles in sheep. Fournal of Endocrinology 77 309-318.

Ottobre JS, Nixon SE \& Stouffer RL 1984 Induction of relaxin in rhesus monkeys by human chorionic gonadotropin: dependence on the age of the corpus luteum of the menstrual cycle. Biology of Reproduction 31 1000-1006.

Quagliarello J, Goldsmith L, Steinetz B, Lustig SL \& Weiss G 1980 Induction of relaxin secretion in pregnant women by human chorionic gonadotropin. Fournal of Clinical Endocrinology and Metabolism 51 74-77.
Ryan PL, Klonisch T, Yamashiro S, Renaud RL, Wasnidge C \& Porter DG 1997 Expression and localization of relaxin in the ovary of the mare. Fournal of Reproduction and Fertility $110329-338$

Ryan PL, Valentine AF \& Bagnell CA 1996 Expression of epithelial cadherin in the developing and adult pig ovary. Biology of Reproduction 55 1091-1097.

Scarbrough K, Weiland NG, Larson GH, Sortino MA, Chiu S, Hirshfield AN \& Wise PM 1991 Measurement of peptide secretion and gene expression in the same cell. Molecular Endocrinology 5 134-142.

Tsang PCW, Walton JS \& Hansel W 1990 Oxytocin-specific RNA, oxytocin and progesterone concentrations in corpora lutea of heifers treated with oxytocin. Fournal of Reproduction and Fertility $8977-84$.

Vaitukaitis JL, Robbins JB, Nieschlog E \& Ross GT 1971 A method for producing specific antisera with small doses of immunogen. Fournal of Clinical Endocrinology and Metabolism 33 988-991.

Wathes DC, Wardle PG, Rees JM, Mitchell JD, Laughlin EA, Hull MGR \& Porter DG 1986 Identification of relaxin immunoreactivity in human follicular fluid. Human Reproduction 8 15-17.

Yki-Jarvinen H, Wahlstrom T, Tenhunen A, Koskimies AI \& Sepala M 1984 The occurrence of relaxin in hyperstimulated human preovulatory follicles collected in an in vitro fertilization program. Fournal of In Vitro Fertilisation and Embryo Transfer 1 180-182.

Zhang Q \& Bagnell CA 1993 Relaxin stimulation of porcine granulosa cell deoxyribonucleic acid synthesis in vitro: interactions with insulin-like growth factor I. Endocrinology 132 1643-1650.

Zhang Q \& Bagnell CA 1994 Trophic actions of relaxin on porcine theca cells: interactions with insulin and insulin-like growth factor-I in vitro. Endocrine Fournal 2 349-355.

RECEIVED 19 January 1998 